Nevada

Environmental

Restoration

Project

\title{
Corrective Action Plan for Corrective Action Unit 139: Waste Disposal Sites, Nevada Test Site, Nevada
}

Controlled Copy No::

Revision: 0

July 2007

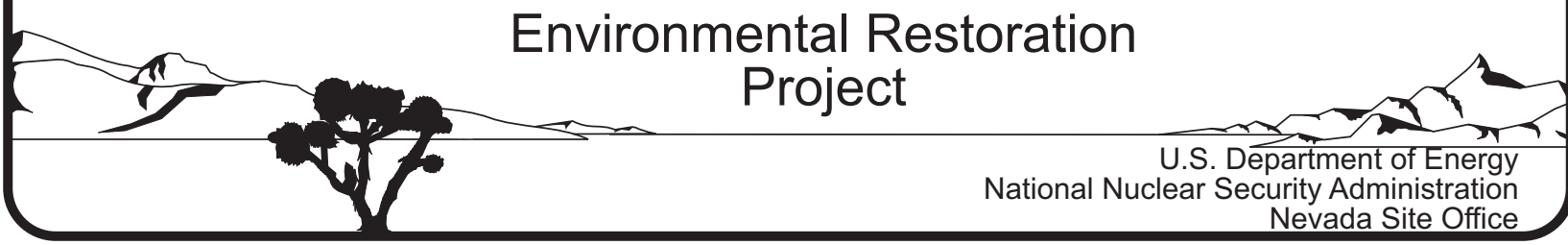




\title{
DISCLAIMER
}

Reference herein to any specific commercial product, process, or service by trade name, trademark, manufacturer, or otherwise, does not necessarily constitute or imply its endorsement, recommendation, or favoring by the United States Government or any agency thereof or its contractors or subcontractors.

This report has been reproduced directly from the best available copy.

Available for sale to the public from:

\author{
U.S. Department of Commerce \\ National Technical Information Service \\ 5285 Port Royal Road \\ Springfield, VA 22161-0002 \\ Telephone: (800) 553-6847 \\ Fax: (703) 605-6900 \\ E-mail: orders@ntis.gov \\ Online ordering: http://www.ntis.gov/ordering.htm
}

Available electronically at http://www.osti.gov/bridge.

Available for a processing fee to the U.S. Department of Energy and its contractors, in paper, from:

U.S. Department of Energy

Office of Scientific and Technical Information

P.O. Box 62

Oak Ridge, TN 37831-0062

Telephone: (865) 576-8401

Fax: (865) 576-5728

E-mail: reports@adonis.osti.gov 


\title{
CORRECTIVE ACTION PLAN FOR CORRECTIVE ACTION UNIT 139: WASTE DISPOSAL SITES, NEVADA TEST SITE, NEVADA
}

\author{
U.S. Department of Energy \\ National Nuclear Security Administration \\ Nevada Site Office \\ Las Vegas, Nevada
}

Controlled Copy No.

Revision: 0

July 2007 
THIS PAGE INTENTIONALLY LEFT BLANK 


\section{CORRECTIVE ACTION PLAN FOR CORRECTIVE ACTION UNIT 139: WASTE DISPOSAL SITES, NEVADA TEST SITE, NEVADA}

Sabine T. Curtis

Acting Federal Sub-Project Director

Industrial Sites Sub-Project

Approved By: SIGNATURE APPROVED

Date: $\underline{07 / 24 / 2007}$

Kevin J. Cabble

Acting Federal Project Director

Environmental Restoration Project 
THIS PAGE INTENTIONALLY LEFT BLANK 


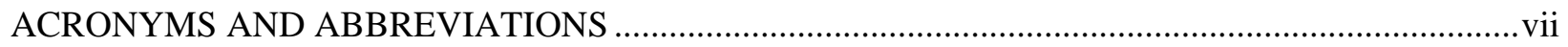

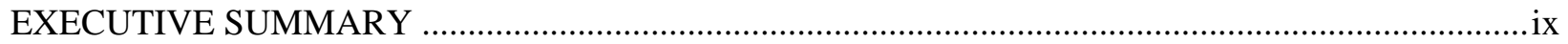

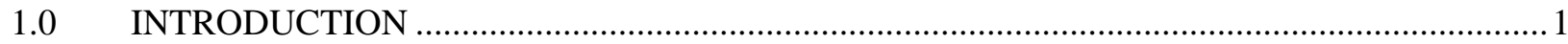

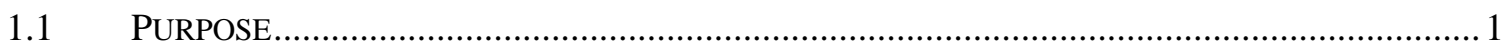

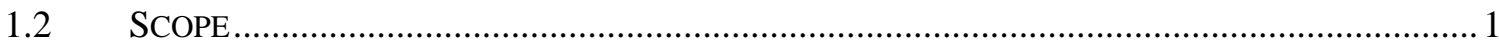

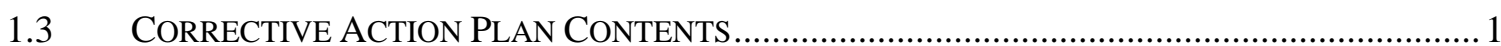

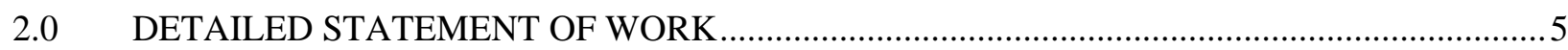

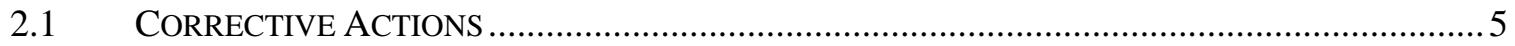

2.1.1 Alternative 1, No Further Action .................................................................... 5

2.1.1.1 Corrective Action Site 04-08-02, Waste Disposal Site ........................ 5

2.1.1.2 Corrective Action Site 06-19-02, Waste Disposal Site/Burn Pit ......... 6

2.1.1.3 Corrective Action Site 09-34-01, Underground Detection Station...... 6

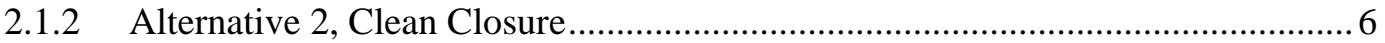

2.1.2.1 Corrective Action Site 03-35-01, Burn Pit ............................................6

2.1.2.2 Corrective Action Site 04-99-01, Contaminated Surface Debris ......... 8

2.1.3 Alternative 3, Close in Place with Administrative Controls .................................. 8

2.1.3.1 Corrective Action Site 06-19-03, Waste Disposal Trenches ................ 8

2.1.3.2 Corrective Action Site 09-23-01, Area 9 Gravel Gertie ..................... 11

2.2 CONSTRUCTION QUALITY ASSURANCE/QUALITY CONTROL ...................................... 11

2.2.1 Construction Field Sample Collection Activities ............................................... 11

2.2.2 Construction Laboratory/Analytical Data Quality Indicators ............................... 13

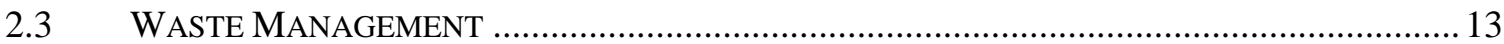

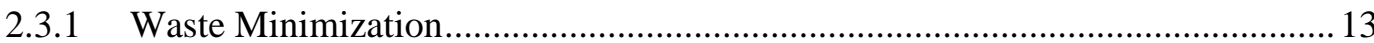

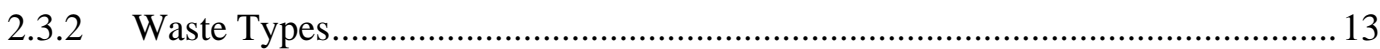

2.3.2.1 Sanitary Waste and Construction Debris ..........................................13

2.3.2.2 Low-Level Waste ................................................................................. 13

2.3.2.3 Hydrocarbon Waste ......................................................................... 14

2.3.2.4 Hazardous Waste .............................................................................. 14

2.3.2.5 Mixed Waste........................................................................................ 14

2.3.2.6 Toxic Substances Control Act-Regulated Waste ............................... 14

2.3.2.7 Decontamination Waste..................................................................... 15

2.3.2.8 Personal Protective Equipment...................................................... 15

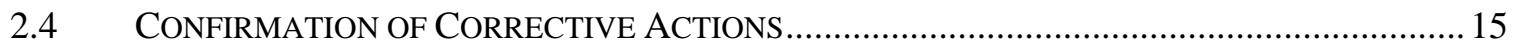

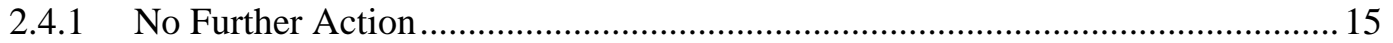

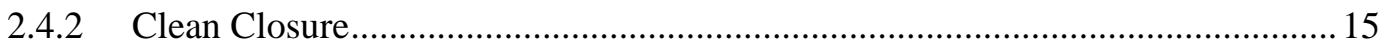

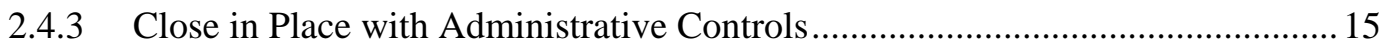

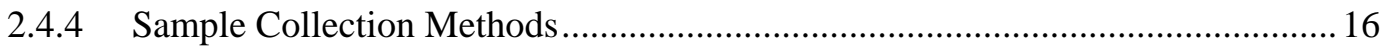

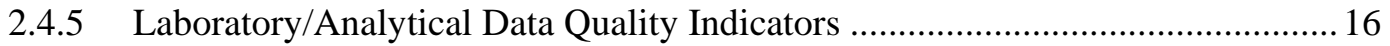

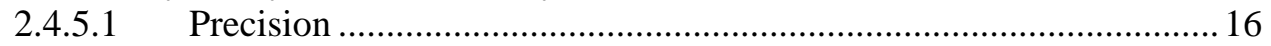

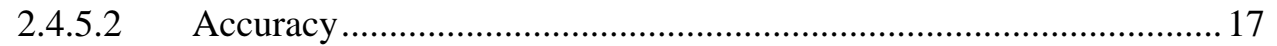

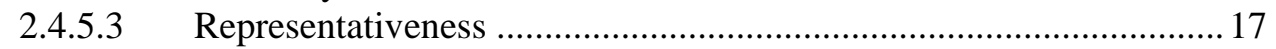

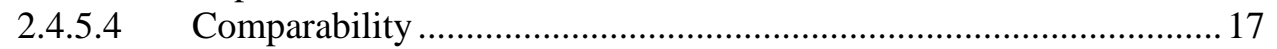

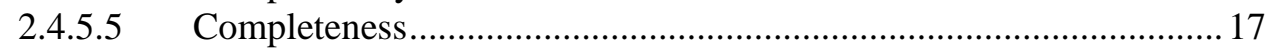

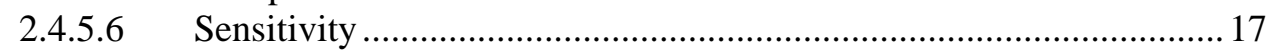

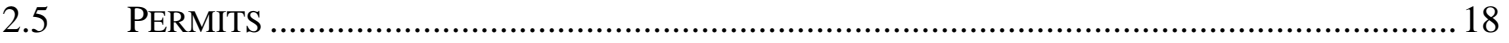

2.5.1 National Environmental Policy Act Checklist ...................................................... 18

2.5.2 Real Estate/Operations Permit ..................................................................... 18 
2.5.3 Radiological Work Permit ........................................................................... 18

2.5.4 Utility Clearances, Excavation Permits, and Blind Penetration Permits .............. 18

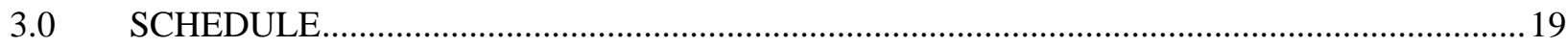

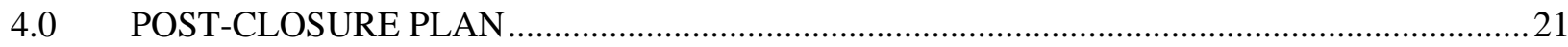

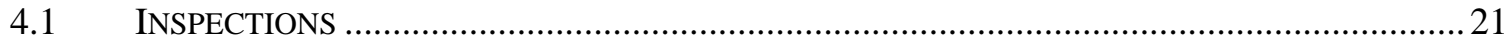

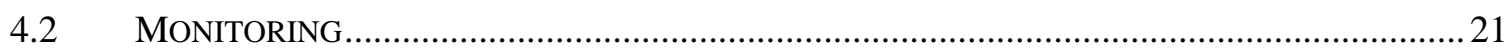

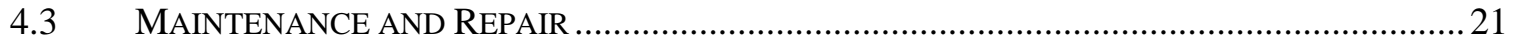

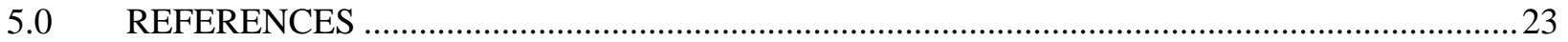

LIBRARY DISTRIBUTION LIST

\section{LIST OF FIGURES}

Figure 1. Corrective Action Unit 139 Site Location Map .............................................. 2

Figure 2. Corrective Action Site 03-35-01, Burn Pit ..................................................... 7

Figure 3. Corrective Action Site 04-99-01, Contaminated Surface Debris ...................... 9

Figure 4. Corrective Action Site 06-19-03, WASte Disposal Trenches ........................... 10

Figure 5. Corrective Action Site 09-23-01, Area 9 Gravel Gertie ................................. 12

\section{LIST OF TABLES}

Table 1. Corrective Action Unit 139 Closure Activities ................................................. 3

\section{LIST OF APPENDICES}

APPENDIX A.1. ENGINEERING SPECIFICATIONS AND DRAWINGS........................................... A.1-1

APPENDIX A.2. SAMPLING AND ANALYSIS PLAN ........................................................... A.2-1

ApPEndix A.3. Project ORgAniZATIOn ........................................................................ A.3-1 


\section{ACRONYMS AND ABBREVIATIONS}

BMP best management practice

CADD

Corrective Action Decision Document

CAIP

Corrective Action Investigation Plan

CAP

Corrective Action Plan

CAS

Corrective Action Site

CAU

Corrective Action Unit

COC

contaminant of concern

CR

Closure Report

DOE

U.S. Department of Energy

DOT

U.S. Department of Transportation

DQI

data quality indicator

DQO

data quality objective

EPA

U.S. Environmental Protection Agency

FAL

final action level

FFACO

Federal Facility Agreement and Consent Order

$\mathrm{ft}$

foot (feet)

HW

hazardous waste

LLW

low-level waste

mi

mile(s)

MW

mixed waste

NCRP

National Council on Radiation Protection

NDEP

Nevada Division of Environmental Protection

NEPA

National Environmental Policy Act

NNSA/NSO

U.S. Department of Energy, National Nuclear Security Administration Nevada Site Office

NNSA/NV

U.S. Department of Energy, National Nuclear Security Administration Nevada Operations Office

NTS

Nevada Test Site

$\% \mathrm{R}$

percent recovery

PAL

preliminary action level

pCi/g

picoCurie(s) per gram

PPE

personal protective equipment 


\section{ACRONYMS AND ABBREVIATIONS (continued)}

$\begin{array}{ll}\mathrm{Pu} & \text { plutonium } \\ \text { QA/QC } & \text { quality assurance/quality control } \\ \text { RPD } & \text { relative percentage difference } \\ \text { REOP } & \text { Real Estate/Operations Permit } \\ \text { RWP } & \text { Radiological Work Permit } \\ \text { TSCA } & \text { Toxic Substances Control Act } \\ \text { UR } & \text { use restriction } \\ \mathrm{yd}^{3} & \text { cubic yard(s) }\end{array}$


Corrective Action Unit (CAU) 139, Waste Disposal Sites, is listed in the Federal Facility Agreement and Consent Order (FFACO) of 1996 (FFACO, 1996). CAU 139 consists of seven Corrective Action Sites (CASs) located in Areas 3, 4, 6, and 9 of the Nevada Test Site, which is located approximately 65 miles northwest of Las Vegas, Nevada. CAU 139 consists of the following CASs:

- CAS 03-35-01, Burn Pit

- CAS 04-08-02, Waste Disposal Site

- CAS 04-99-01, Contaminated Surface Debris

- CAS 06-19-02, Waste Disposal Site/Burn Pit

- CAS 06-19-03, Waste Disposal Trenches

- CAS 09-23-01, Area 9 Gravel Gertie

- CAS 09-34-01, Underground Detection Station

Site characterization of the CAU 139 CASs was performed in 2006, and the results are presented in Appendix A of the CAU 139 Corrective Action Decision Document (U.S. Department of Energy, National Nuclear Security Administration Nevada Site Office, 2007). The scope of work required to implement the recommended closure alternatives is summarized below.

- CAS 03-35-01, Burn Pit, contains plutonium (Pu)-239 above the final action level (FAL). The site will be clean closed by removing contaminated soil and debris at two locations. In addition, as a best management practice (BMP), geophysical anomalies will be excavated, and all surface debris will be removed for disposal.

- CAS 04-08-02, Waste Disposal Site, contains no contaminants of concern (COCs) above FALs. No further action is required for this site; however, as a BMP, this area will be recorded in the Facilities Information Management System database as an administrative use restriction (UR) area. No postings or post-closure monitoring will be required.

- CAS 04-99-01, Contaminated Surface Debris, contains Pu-239 above the FAL. The site will be clean closed by removing contaminated soil and debris at one location. In addition, as a BMP, geophysical anomalies will be excavated, and all surface debris will be removed for disposal.

- CAS 06-19-02, Waste Disposal Site/Burn Pit, contains no COCs above FALs. No further action is required for this site, and no work will be performed.

- CAS 06-19-03, Waste Disposal Trenches, will be closed in place with administrative controls. An engineered soil cover will be installed with a minimum thickness of 2 feet, at a 2- to 4-percent slope. Monuments will be installed, UR warning signs will be posted, and a UR will be implemented. In addition, as a BMP, the water line that currently runs through the CAS will be diverted to a location outside the CAS.

- CAS 09-23-01, Area 9 Gravel Gertie, is identified as an Underground Radioactive Materials Area. The site will be closed in place with administrative controls. UR warning signs have been posted, and a UR will be implemented. 


\section{EXECUTIVE SUMMARY (continued)}

- CAS 09-34-01, Underground Detection Station, contains no COCs above FALs. No further action is required for this site, and no work will be performed. 


\subsection{INTRODUCTION}

Corrective Action Unit (CAU) 139, Waste Disposal Sites, is listed in the Federal Facility Agreement and Consent Order (FFACO) of 1996 (FFACO, 1996). CAU 139 consists of seven Corrective Action Sites (CASs) located in Areas 3, 4, 6, and 9 of the Nevada Test Site (NTS), which is located approximately 65 miles (mi) northwest of Las Vegas, Nevada (Figure 1). CAU 139 consists of the following CASs:

- CAS 03-35-01, Burn Pit

- CAS 04-08-02, Waste Disposal Site

- CAS 04-99-01, Contaminated Surface Debris

- CAS 06-19-02, Waste Disposal Site/Burn Pit

- CAS 06-19-03, Waste Disposal Trenches

- CAS 09-23-01, Area 9 Gravel Gertie

- CAS 09-34-01, Underground Detection Station

Details of the site history and site characterization results for CAU 139 are provided in the approved Corrective Action Investigation Plan (CAIP) (U.S. Department of Energy, National Nuclear Security Administration Nevada Site Office [NNSA/NSO], 2006) and in the approved Corrective Action Decision Document (CADD) (NNSA/NSO, 2007).

\subsection{Purpose}

The purpose of this Corrective Action Plan (CAP) is to present the detailed scope of work required to implement the recommended corrective actions as specified in Section 4.0 of the approved CADD (NNSA/NSO, 2007).

\subsection{SCOPE}

The approved closure activities for CAU 139 include removal of soil and debris contaminated with plutonium $(\mathrm{Pu})-239$, excavation of geophysical anomalies, removal of surface debris, construction of an engineered soil cover, and implementation of use restrictions (URs). Table 1 presents a summary of CAS-specific closure activities and contaminants of concern (COCs). Specific details of the corrective actions to be performed at each CAS are presented in Section 2.0 of this report.

\subsection{Corrective Action Plan Contents}

This CAP consists of the following sections and appendices:

- Section 1.0: Introduction

- Section 2.0: Detailed Statement of Work

- Section 3.0: Schedule

- Section 4.0: Post-Closure Plan

- Section 5.0: References 


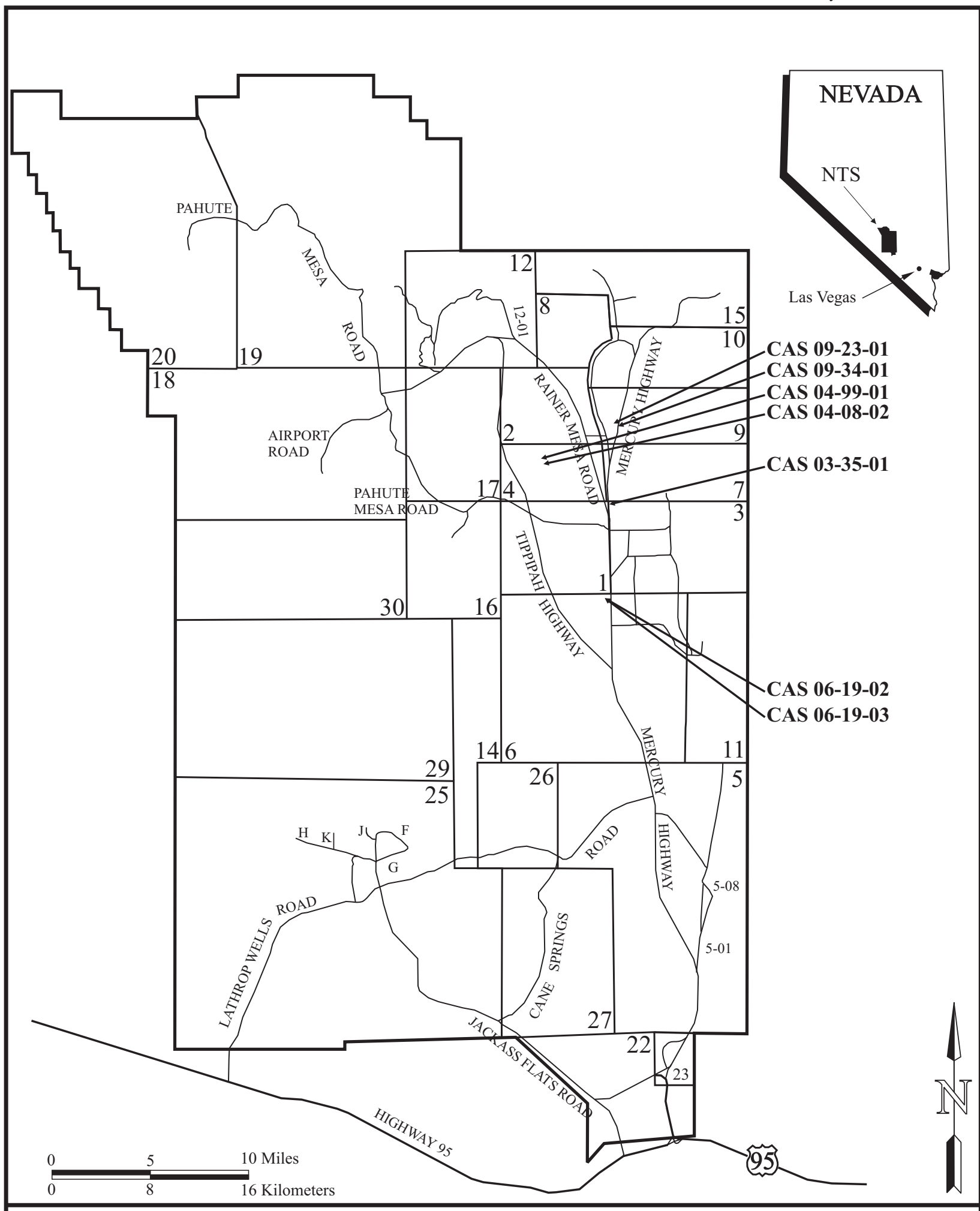

Figure 1. Corrective ACtion Unit 139 Site Location MaP 
Table 1. Corrective Action Unit 139 Closure Activities

\begin{tabular}{|c|c|c|c|c|}
\hline CAS & Name & Closure Method & COCs & Scope of Work \\
\hline 03-35-01 & Burn Pit & Clean Closure & Pu-239 & $\begin{array}{l}\text { - } \quad \text { Remove contaminated soil and debris at two locations } \\
\text { - } \quad \text { Collect verification samples } \\
\text { - } \quad \text { As a BMP, excavate geophysical anomalies and remove surface } \\
\text { - } \quad \text { debris for disposal } \\
\text { Restore site to natural contours with clean fill as necessary }\end{array}$ \\
\hline 04-08-02 & Waste Disposal Site & No Further Action & None & - As a BMP, implement administrative UR \\
\hline 04-99-01 & Contaminated Surface Debris & Clean Closure & $\mathrm{Pu}-2$ & $\begin{array}{l}\text { - } \\
\text { - } \\
\text { - } \\
\text { - } \\
\text { As a BMPoct verification samples } \\
\text { debris for disposal } \\
\text { - } \\
\text { Restore site to natural contours with clean fill as necessary }\end{array}$ \\
\hline $06-19-02$ & Waste Disposal Site/Burn Pit & No Further Action & None & None \\
\hline 06-19-03 & Waste Disposal Trenches & Closure in Place & Assum & 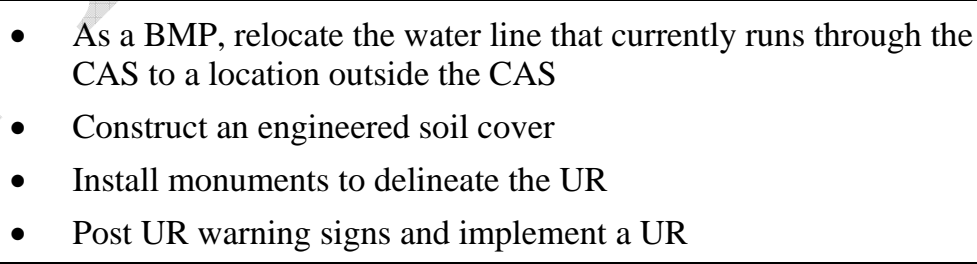 \\
\hline 09-23-01 & Area 9 Gravel Gertie & Closure in Place & Assumed $^{\mathrm{B}}$ & - $\quad$ Implement a UR \\
\hline $09-34-01$ & Underground Detection Station & No Further Action & None & None \\
\hline
\end{tabular}

BMP: best management practice

CAS: Corrective Action Site

COCs: contaminants of concern

Pu: plutonium

UR: use restriction

A The landfill contents could not be sufficiently characterized to preclude the potential presence of COCs; therefore, a conservative assumption was made that COCs exist within the landfill.

${ }^{\text {B }}$ No environmental samples were collected at this CAS; however, based on process knowledge and the investigation of a similar CAS, it is assumed to contain uranium. 
- Appendix A.1: Engineering Specifications and Drawings

- Appendix A.2: Sampling and Analysis Plan

- Appendix A.3: Project Organization

- Library Distribution List

Appendix A.2 is included as required by the approved FFACO outline, but contains no material. Sufficient detail on the type, number, and location of verification samples to be collected to verify site closure activities has been provided in Section 2.4 of this report. 


\subsection{DETAILED STATEMENT OF WORK}

The approved corrective actions, as evaluated in Section 3.0 of the CADD and identified in Section 4.0 of the CADD (NNSA/NSO, 2007) for CAU 139, include:

- CAS 03-35-01, Burn Pit: Clean Closure

- CAS 04-08-02, Waste Disposal Site: No Further Action

- CAS 04-99-01, Contaminated Surface Debris: Clean Closure

- CAS 06-19-02, Waste Disposal Site/Burn Pit: No Further Action

- CAS 06-19-03, Waste Disposal Trenches: Close in Place with Administrative Controls

- CAS 09-23-01, Area 9 Gravel Gertie: Close in Place with Administrative Controls

- CAS 09-34-01, Underground Detection Station: No Further Action

\subsection{Corrective ACtions}

The corrective action alternatives for CAU 139 are identified in Section 4.0 of the CADD (NNSA/NSO, 2007) and were approved by the Nevada Division of Environmental Protection (NDEP). The objective of the corrective actions is to prevent or mitigate adverse environmental impacts and migration of contamination. The corrective actions and best management practices (BMPs) for CAU 139 are identified below.

\subsubsection{Alternative 1, No Further Action}

\subsubsection{Corrective Action Site 04-08-02, Waste Disposal Site}

This site is located in Area 4 of the NTS, approximately $0.5 \mathrm{mi}$ south of the intersection of the 4-04 Road and Orange Road. Radioactive debris from various activities at the NTS was consolidated and stored at the site for an undetermined length of time. This debris is no longer present at the site.

No COCs are present above final action levels (FALs) at this site. Cesium-137, europium-152, and europium-154 are present at concentrations above the preliminary action levels (PALs), which were based on recommendations in the National Council on Radiation Protection (NCRP) Report No. 129 (NCRP, 1999) for screening limits for construction, commercial, and industrial land-use scenarios, scaled to a 25 millirem per year dose constraint. However, the radioisotopes did not exceed the FALs that were calculated using the Residual Radioactive Computer Code based on a remote area scenario (Murphy, 2004) and are therefore not considered COCs. In addition, Pu-239 is present at concentrations above the PAL; however, Pu-239 contamination is attributable to atmospheric tests and will be addressed under the Soils Project. Since Pu-239 contamination is not attributable to CAS 04-08-02, it is not considered a COC.

No further action is required for this site; however, as a BMP, the area will be recorded in the Facilities Information Management System database as an administrative UR to protect future workers from an exposure should the land use scenario change from that used to calculate the FALs. No postings or post-closure monitoring will be required. 


\subsubsection{Corrective Action Site 06-19-02, Waste Disposal Site/Burn Pit}

This site is located in Area 6 of the NTS, approximately 300 feet $(\mathrm{ft})$ west of Well 3. The site was associated with the operation of the Area 6 U.S. Environmental Protection Agency (EPA) Farm and includes an animal pen, a fenced area referred to as a burn pit, and a waste disposal site adjacent to the burn pit. The animal pen and fence were removed during site characterization activities for CAU 139.

No COCs are present above FALs at this site. No further action is required, and no work will be performed.

\subsubsection{Corrective Action Site 09-34-01, Underground Detection Station}

This site, located in Area 9 of the NTS, consists of an underground bunker located on the northeast corner of the intersection of the 9-01 Road and Old Mercury Highway. The concrete bunker, known as both Bunker 9-300 and Bunker Z-900, is approximately $15 \mathrm{ft}$ below ground surface and was used to house detection equipment for monitoring several nuclear tests conducted throughout the area.

No environmental samples were collected during site characterization because, based on process knowledge of the site, no potential releases were identified. Therefore, no further action is required, and no work will be performed. As a BMP, a safety fence restricting access to the entrance to the underground bunker was installed during site characterization activities for CAU 139.

\subsubsection{Alternative 2, Clean Closure}

\subsubsection{Corrective Action Site 03-35-01, Burn Pit}

This site is located in Area 3 of the NTS, approximately $0.25 \mathrm{mi}$ northeast of the intersection of Mercury Highway and Rainier Mesa Road (Figure 2). The site consists of two small burn areas with charred soil and debris. The debris, which includes cinder blocks, rusted cans, cable, concrete, and charred wood, may have originated from activities related to the U-3gg crater, former Building 3-51, the old balloon launch pad, the Area 3 burn pit, or nearby arsenic-contaminated soil piles. Four geophysical anomalies are present. During site characterization activities, the areas of the anomalies were excavated and confirmed to contain buried concrete and metal.

At the two burn areas, $\mathrm{Pu}-239$ is present above the FAL at a maximum concentration of 19.1 picoCuries per gram (pCi/g). The site will be clean closed by removing approximately 10.5 cubic yards $\left(\mathrm{yd}^{3}\right)$ of contaminated charred soil and debris for disposal as low-level waste (LLW). A minimum of four verification samples, one from a randomly selected side wall and one from the floor of each excavation, will be collected and analyzed for Pu-239. If verification sample results indicate that the action level is exceeded, additional soil will be removed, and additional verification samples will be collected. Upon verifying that the contaminated soil has been removed, the excavations will be backfilled with clean soil and contoured to the approximate surrounding topographic grade. 
NOTE: A total of $\sim 10.5 \mathrm{yd}^{3}$ of plutonium-239-impacted soil will be excavated from $\mathrm{B} 02$ and $\mathrm{B} 03$.

Surface debris will be removed, and subsurface debris located at the four geophysical anomalies will be excavated as a best management practice.
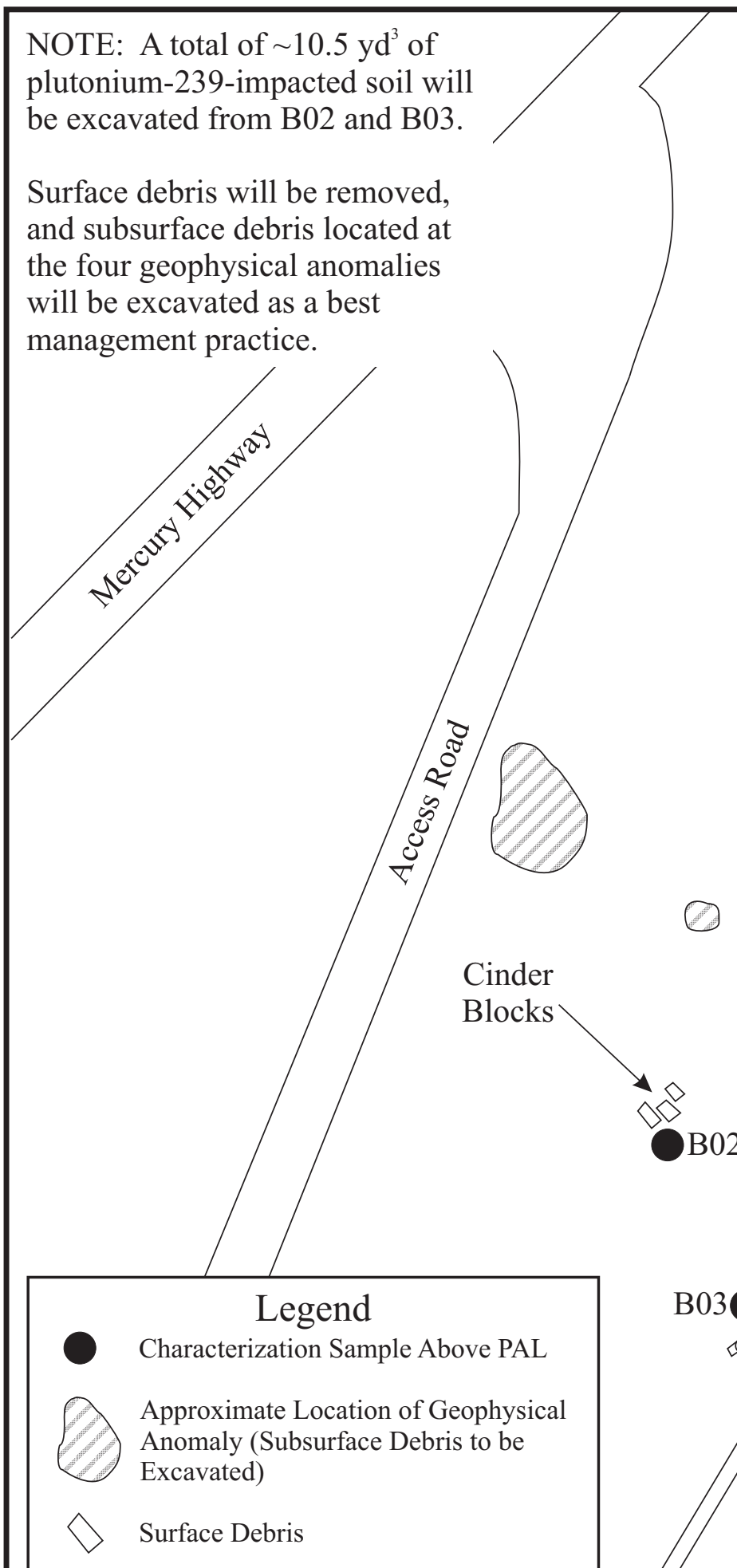
As a BMP, a total of approximately $76 \mathrm{yd}^{3}$ of subsurface debris will be excavated from the areas of the four geophysical anomalies, and all surface debris will be removed for disposal as sanitary waste. The excavations will be backfilled with clean soil and contoured to the approximate surrounding topographic grade.

\subsubsection{Corrective Action Site 04-99-01, Contaminated Surface Debris}

This site is located in Area 4 of the NTS, approximately $75 \mathrm{ft}$ west of the intersection of the 4-04 Road and Orange Road (Figure 3). Radioactive debris from various activities at the NTS had been consolidated and stored at the site for an undetermined length of time, but is no longer present at the site. The site consists of two small berms, two shallow trenches, surface debris consisting of rusted cans, and two geophysical anomalies. During site characterization activities, the areas of the anomalies were excavated and confirmed to contain small, buried metal objects.

$\mathrm{Pu}-239$ is present above the FAL in one of the shallow trenches at a maximum concentration of $14.5 \mathrm{pCi} / \mathrm{g}$. The contamination is associated with the rusted cans present at the site. The site will be clean closed by removing approximately $2 \mathrm{yd}^{3}$ of contaminated soil and debris for disposal as LLW. A minimum of two verification samples, one from a randomly selected side wall and one from the floor of the excavation, will be collected and analyzed for Pu-239. If verification sample results indicate that the action level is exceeded, additional soil will be removed, and additional verification samples will be collected. Upon verifying that the contaminated soil has been removed, the excavation will be backfilled with clean soil and contoured to the approximate surrounding topographic grade.

As a BMP, a total of approximately $21 \mathrm{yd}^{3}$ of subsurface debris will be excavated from the areas of the two geophysical anomalies, and all surface debris will be removed for disposal as sanitary waste. The excavations will be backfilled with clean soil and contoured to the approximate surrounding topographic grade.

\subsubsection{Alternative 3, Close in Place with Administrative Controls}

\subsubsection{Corrective Action Site 06-19-03, Waste Disposal Trenches}

This site is located in Area 6 of the NTS, approximately $700 \mathrm{ft}$ north of Well 3 (Figure 4). The site consists of waste trenches containing the buried remains of Area 6 EPA Farm animals and associated waste from operations at the Area 6 EPA Farm. One of the disposal trenches was discovered in 2004 during the installation of a water line through the site running from Well 3 to the U1a site, and the contents of the trench were unintentionally exposed. Items excavated included a cow carcass, liquid samples in plastic jugs, and multiple animal bones. At the time the trench was discovered in 2004, liquid, soil, and sludge samples were collected directly from excavated soil and waste and analyzed, and the results did not exceed the current regulatory thresholds or NTS sanitary waste landfill limits for any of the constituents. The excavated items were packaged and disposed as sanitary waste.

Site characterization conducted in 2006 consisted of collecting samples from areas outside the waste trenches (NNSA/NSO, 2007). No COCs were identified based on the samples collected outside the waste trenches; therefore, no COCs have migrated laterally beyond the boundaries of the landfill. Even though the direct sampling of waste in 2004 did not identify any COCs, the 
NOTE: A total of $\sim 2 \mathrm{yd}^{3}$ of

plutonium-239-impacted soil will

be excavated from D01.

Surface debris will be removed, and subsurface debris located at the two geophysical anomalies will be excavated as a best management practice.

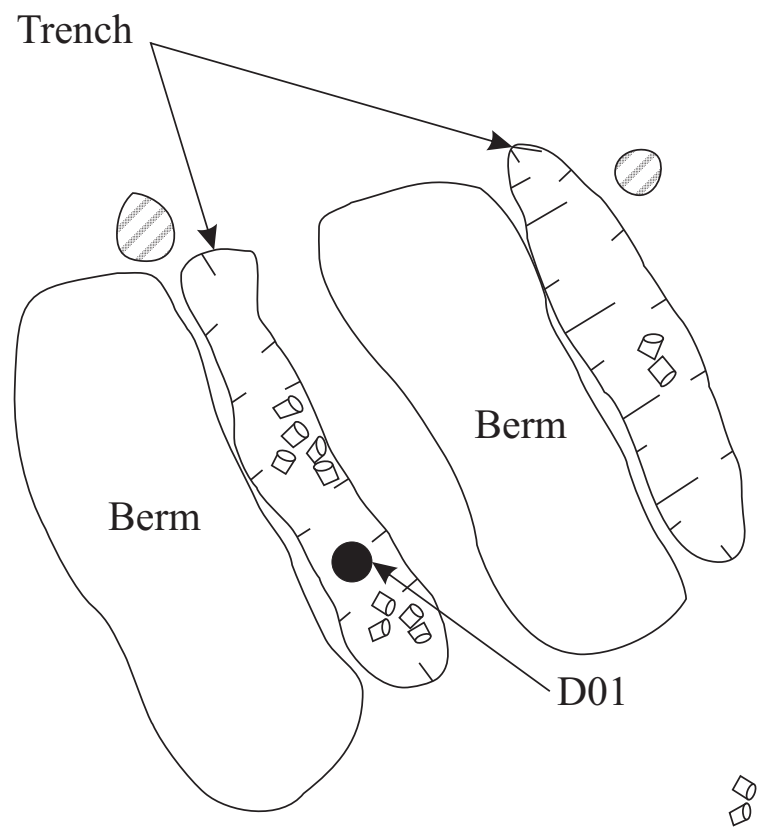

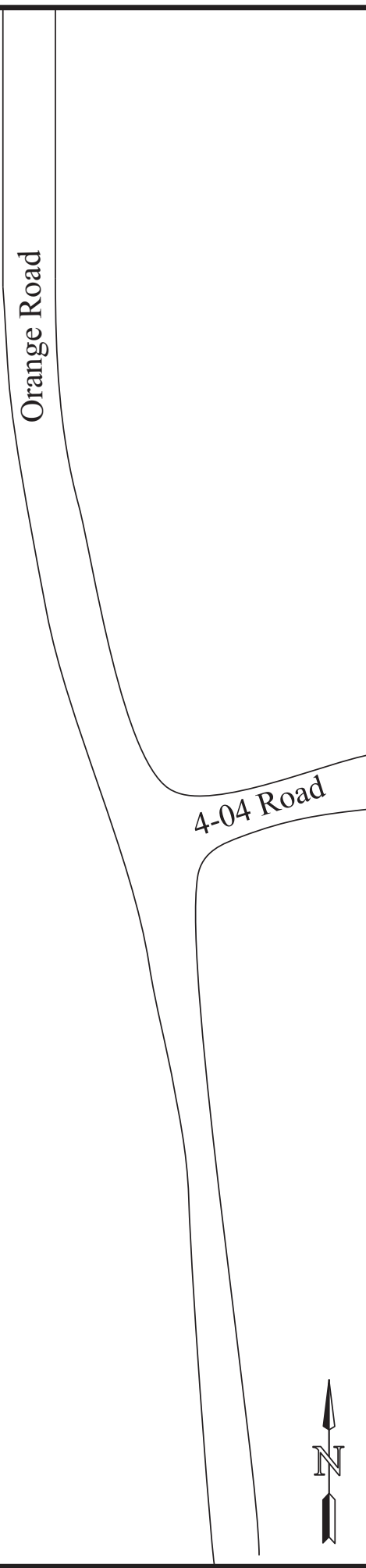

Figure 3. Corrective ACtion Site 04-99-01, Contaminated Surface Debris 
NOTE: The water line will be diverted to a location outside the waste trenches.

An engineered soil cover will be constructed over the waste trenches, and use restriction warning signs and monuments will be installed around the site.
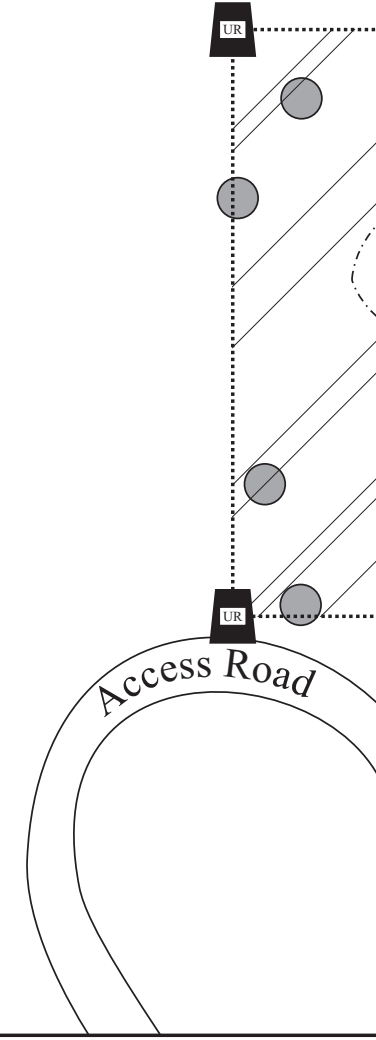

\section{Legend}

Characterization Sample (All Results Below PALs)

-. - - Current Location of Water Line

Approximate Boundary of Waste Trench

Approximate Boundary of Engineered Soil Cover and Use Restriction

Approximate Location of Monument and Use Restriction Warning Sign
Approximate Boundary of Engineered Soil Cover and Use Restriction

$(\sim 200 \mathrm{ft} \times 285 \mathrm{ft})$

Approximate Location of Waste Trenches 
landfill contents could not be sufficiently characterized to preclude the potential presence of COCs. Therefore, a conservative assumption was made that radioactive and/or hazardous COCs exist within the landfill.

The site will be closed in place with administrative controls. As a BMP, the water line that runs through the CAS will be diverted to a location outside of the CAS. An engineered soil cover will be installed with a minimum thickness of $2 \mathrm{ft}$, at a 2- to 4-percent slope. The engineering specifications and drawings for this cover are included as Appendix A.1 of this document. Monuments will be installed to delineate the UR area, and UR warning signs will be posted. A UR will be implemented to prohibit any unauthorized intrusive activity. The corrective actions will be confirmed by visual inspection and photographic documentation of the final site conditions, and the cover will be as-built surveyed. Annual site inspections will be required to ensure that the signs are intact and legible and that the UR is maintained.

\subsubsection{Corrective Action Site 09-23-01, Area 9 Gravel Gertie}

This site is located in Area 9 of the NTS, along the 9-01 Road between Old Mercury Highway and Circle Road (Figure 5). The site consists of potential contamination generated during the 1958 Ganymede safety experiment, which involved the zero-yield detonation of four devices composed of uranium and plastic-bonded explosives within a gravel structure. The gravel gertie was designed to function so that the gravel structure would expand during detonation and then settle to near its original shape while retaining the contaminated particles within the gravel. The site includes the gravel gertie, a large gravel pile located directly to the east of the gertie, a concrete vault, and a circular vault. The site is fenced and posted with signs identifying underground radioactive material.

No environmental samples were collected during site characterization because, based on process knowledge and the investigation of a similar CAS, it is assumed to contain uranium. The site will be closed in place with administrative controls. UR warning signs were posted during site characterization activities for CAU 139. A UR will be implemented to prohibit any unauthorized intrusive activity. Annual site inspections will be required to ensure that the signs are intact and legible and that the UR is maintained.

\subsection{CONSTRUCTION QUALITY ASSURANCE/QUALITY CONTROL}

Construction activities will include removal of contaminated soil and debris, implementation of URs, and construction of an engineered soil cover over the disposal trenches at CAS 06-19-03, Waste Disposal Trenches. Engineering specifications and drawings for the landfill cover at CAS 06-19-03 are provided in Appendix A.1 of this report.

\subsubsection{Construction Field Sample Collection Activities}

Soil samples will be collected for the purpose of waste stream characterization and to verify that the closure objectives have been met. Sample collection activities are addressed in Section 2.4 of this report. 


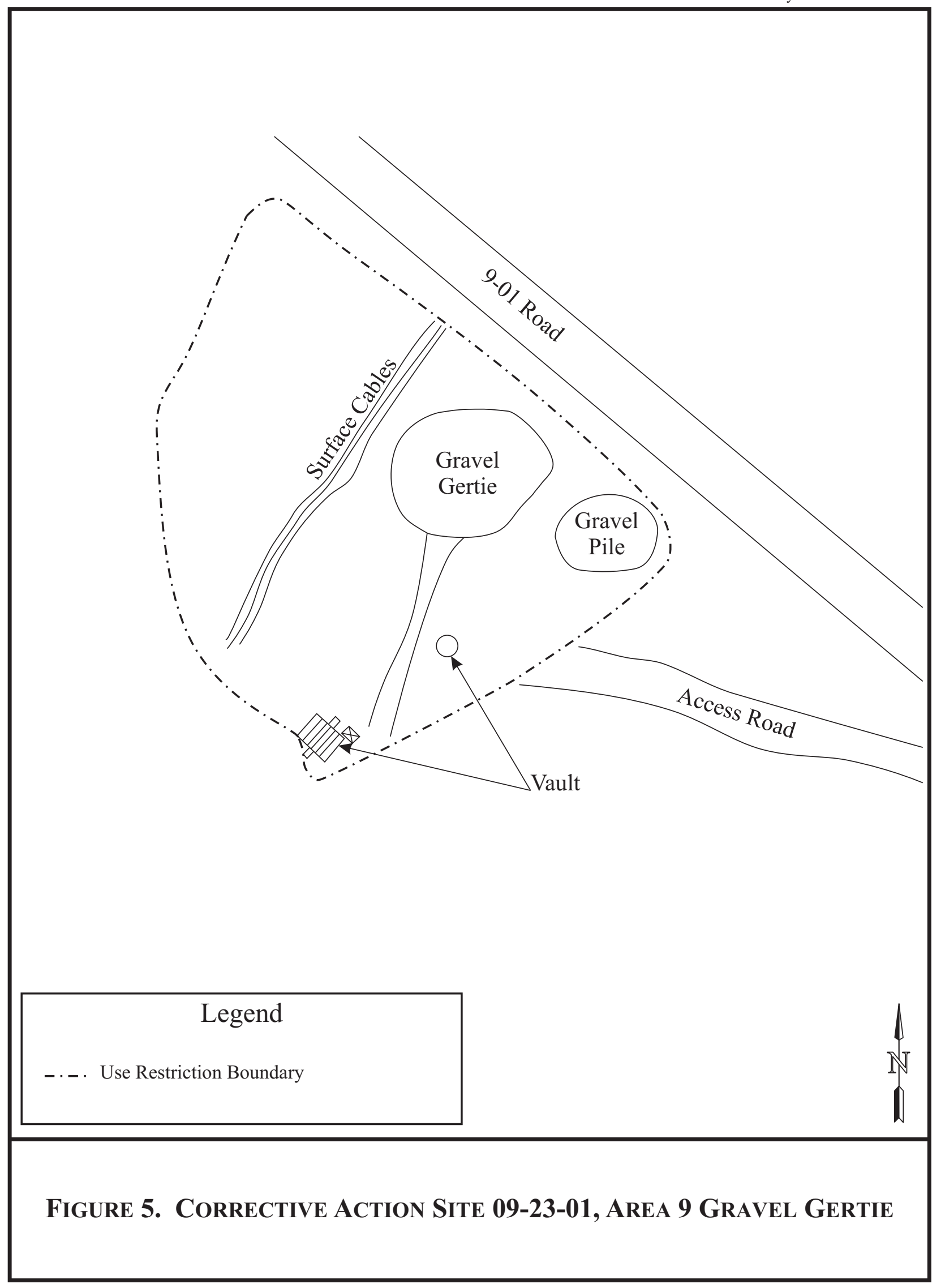


For the construction of the engineered soil cover at CAS 06-19-03, Waste Disposal Trenches, the first two lifts of cover soil must be compacted to a minimum of 80 percent and a maximum of 85 percent. Subsequent lifts of cover soil must be compacted to a minimum of 85 percent and a maximum of 90 percent. Test plots will be constructed using the same soil and equipment to be used in the cover construction to develop performance standards to determine the minimum required number of passes to achieve the required density for each lift of placed soil. Field density tests will be performed at a minimum of two random locations per test plot lift.

\subsubsection{Construction Laboratory/Analytical Data Quality Indicators}

CAU 139 closure activities are limited to removal of soil and debris, implementation of URs, and the installation of a native soil cover. Therefore, a construction quality assurance/quality control (QA/QC) plan is not required, and construction data quality indicators (DQIs) are not applicable. To ensure that backfill material remains consistent, all fill will be taken from an approved borrow source.

\subsection{WASTE MANAGEMENT}

All waste streams will be managed and disposed according to applicable federal and state regulations, U.S. Department of Energy (DOE) Orders, U.S. Department of Transportation (DOT) regulations, and company waste management procedures. CAU 139 closure activities are expected to generate sanitary waste/construction debris and low-level waste (LLW). Although not expected, if hydrocarbon waste, hazardous waste (HW), mixed waste (MW), and/or Toxic Substances Control Act (TSCA)-regulated waste is generated, it will be properly managed and shipped to an appropriate onsite or offsite disposal facility. Confirmation of waste disposal will be included in the CAU 139 Closure Report (CR).

\subsubsection{Waste Minimization}

All work activities that generate waste will strive to minimize the volume of waste generated. Special care will be taken to properly characterize and segregate waste streams to avoid the generation of additional waste.

\subsubsection{Waste Types}

\subsubsection{Sanitary Waste and Construction Debris}

Sanitary waste (e.g., non-impacted personal protective equipment [PPE] and general trash) and construction debris (e.g., wood, concrete, metal, plastic) removed from sites will be radiologically screened for free release (U.S. Department of Energy, Nevada Operations Office, 2004) and disposed as sanitary waste in an onsite permitted landfill.

\subsubsection{Low-Level Waste}

Closure activities are expected to generate LLW at CAS 03-35-01, Burn Pit, and CAS 04-99-01, Contaminated Surface Debris. The waste will be characterized by process knowledge, laboratory analysis of samples, and/or radiological screening results, and a profile for disposal will be prepared. Where waste characterization samples collected during the corrective action 
investigation are adequate to properly characterize and profile the waste, additional samples will not be collected. Where additional analysis is required, samples will be analyzed for those parameters that are missing so as to complete the waste characterization and profile. All LLW will be managed and disposed according to all applicable federal and state regulations, DOE Orders, DOT regulations, and company waste management procedures. All LLW will be packaged under the guidance of a Waste Certification Official and Waste Generator Services personnel. LLW will be stored in a radioactive materials area until a waste disposal profile is prepared and approved, and transport to an appropriate disposal facility can be arranged.

\subsubsection{Hydrocarbon Waste}

Hydrocarbon waste is not expected at CAU 139; however, if it is generated, the waste will be analyzed for gamma-emitting radionuclides by either the In-Situ Object Counting System or laboratory analysis, in order to satisfy the landfill disposal restrictions. Upon receipt of the analytical results, the waste will be properly disposed. Any waste meeting the land disposal restrictions as specified in the landfill permit will be disposed at the Area 6 Hydrocarbon Landfill.

\subsubsection{Hazardous Waste}

HW is not expected at CAU 139; however, if it is generated, the waste will be characterized by process knowledge and/or laboratory analysis, and a waste profile for disposal will be prepared. All HW will be managed and disposed according to all applicable federal and state regulations, DOE Orders, DOT regulations, and company waste management procedures. Upon generation, HW will be containerized and stored in a satellite accumulation area or a 90-day HW accumulation area, depending on the amount of waste generated. After an approved waste profile is generated, the waste will be disposed at a permitted offsite treatment, storage, and disposal facility.

\subsubsection{Mixed Waste}

MW is waste containing both radioactive waste and HW constituents. MW is not expected at CAU 139; however, if it is generated, the waste will be managed and disposed according to all applicable federal and state regulations, DOE Orders, DOT regulations, and company waste management procedures. All MW will be packaged under the guidance of a Waste Certification Official and Waste Generator Services personnel. When staged onsite, the MW will be stored in a radioactive materials area and 90-day HW accumulation area until a waste disposal profile is prepared and approved. Samples will be collected to enable completion of a treatability study, if necessary. The MW will be disposed at a permitted offsite treatment, storage, and disposal facility.

\subsubsection{Toxic Substances Control Act-Regulated Waste}

TSCA-regulated waste is not expected at CAU 139; however, if it is generated, the waste will be characterized by process knowledge and/or laboratory analysis, and a waste profile for disposal will be prepared. All TSCA-regulated waste will be managed and disposed according to all applicable federal and state regulations, DOE Orders, DOT regulations, and company waste 
management procedures. After an approved waste profile is generated, the waste will be disposed at an appropriate TSCA-regulated disposal facility.

\subsubsection{Decontamination Waste}

All radiologically impacted equipment will be surveyed prior to release from an exclusion zone. Any equipment that becomes contaminated during closure activities will be decontaminated onsite. Dry decontamination will be the preferred method. For larger pieces of equipment that cannot be effectively decontaminated using dry decontamination techniques, wet decontamination techniques will be used. All decontamination rinsate will be managed appropriately according to applicable regulations and, once characterized, properly disposed.

\subsubsection{Personal Protective Equipment}

All PPE that becomes contaminated during closure activities will be disposed with the appropriate waste stream.

\subsection{COnfiRmation of CoRrective ACtions}

Accurate and defensible analytical data will be collected to characterize waste and verify that the closure objectives are met. In addition, visual inspection and photographic documentation will verify final site conditions.

\subsubsection{No Further Action}

No COCs are present above FALs at the following sites, and confirmation of corrective action will not be required:

- CAS 04-08-02, Waste Disposal Site

- CAS 06-19-02, Waste Disposal Site/Burn Pit

- CAS 09-34-01, Underground Detection Station

\subsubsection{Clean Closure}

CAS 03-35-01, Burn Pit, and CAS 04-99-01, Contaminated Surface Debris, will be considered clean closed after laboratory results verify that verification samples are below the applicable action levels. In addition, removal of surface debris and subsurface debris at the geophysical anomaly sites will be confirmed by visual inspection and photographic documentation of final site conditions.

\subsubsection{Close in Place with Administrative Controls}

For CAS 06-19-03, Waste Disposal Trenches, and CAS 09-23-01, Area 9 Gravel Gertie, completion of corrective actions will be verified by visual inspection and photographic documentation of final site conditions. 


\subsubsection{Sample Collection Methods}

All soil verification samples will be collected by qualified personnel using standard sampling procedures. Sample collection date, time, and other pertinent information will be logged on a "Service Request and Chain of Custody Record," and recorded in a bound project field notebook. Samples will be collected by hand, using disposable pre-cleaned or decontaminated sampling equipment. All samples will be collected in clean containers, labeled with a unique sample identification number using the CAS number followed by the sample number (e.g., 033501-V1), sealed with a tamper-proof seal, bagged, placed on ice in a cooler, and transported to an offsite analytical laboratory following strict chain of custody. Samples will be analyzed by EPA-approved analytical methods at EPA-approved laboratories (EPA, 1996). Sample analysis will include laboratory analysis of QA/QC samples and will follow stringent QA/QC procedures (EPA, 1996). Sample analysis for radioisotopes will be performed in accordance with Environmental Measurements Laboratory Procedures Manual (DOE, 1997).

One set of QA/QC samples will be collected for every twenty environmental samples or with every batch of samples submitted for laboratory analysis, whichever is greater. QA/QC samples will include blind duplicates, matrix spike/matrix spike duplicates, and equipment rinsate samples. All blind duplicates will be labeled with a unique sample number. All samples will be collected according to the Industrial Sites Quality Assurance Project Plan (U.S. Department of Energy, National Nuclear Security Administration Nevada Operations Office [NNSA/NV], 2002).

\subsubsection{Laboratory/Analytical Data Quality Indicators}

Data Quality Objectives (DQOs) are qualitative and quantitative statements that specify the quality of the data required supporting closure of a site. The DQOs for CAU 139 were defined in Appendix A of the CAIP (NNSA/NSO, 2006). Conceptual site models were developed, and these models were reconciled with the results of the site investigation in the CADD (NNSA/NSO, 2007).

CAS 03-35-01, Burn Pit, and CAS 04-99-01, Contaminated Surface Debris, will be clean closed and will require the collection and analysis of verification samples. If it is required, waste characterization samples will be collected for disposal purposes. All laboratory data generated during closure activities will be reviewed by project personnel to ensure the data are usable and complete according to the CAU 139 DQOs. In addition, as specified in the Industrial Sites Quality Assurance Project Plan (NNSA/NV, 2002), 100 percent of the data packages will be evaluated at the Tier I and Tier II levels. Any data determined not to be valid will be identified in the CR.

DQIs are qualitative and quantitative statements that specify the data requirements of a project. The DQIs include precision, accuracy, representativeness, comparability, completeness, and sensitivity. These DQIs are discussed below.

\subsubsection{Precision}

Precision is a measure of agreement among a replicate set of measurements of the same property under similar conditions. This agreement is expressed as the relative percentage difference (RPD) between duplicate measurements. Precision applies to parameters sampled and analyzed in duplicate. 
One duplicate sample will be collected per set of twenty or fewer verification samples. All duplicate samples will be collected from the same medium and analyzed for the same set of analytes. The precision of the analytical results will be assessed by calculating the RPD for a verification sample and its duplicate sample results. An RPD of less than or equal to 30 percent indicates acceptable precision (NNSA/NV, 2002).

\subsubsection{Accuracy}

Accuracy is a measure of the closeness of an individual measurement or the average of a number of measurements to the true value. Accuracy includes a combination of random error (precision) and systematic error (bias) components that result from sampling and analytical operations. This closeness is expressed as percent recovery (\%R). Accuracy will be assessed by examining the $\% \mathrm{R}$ of laboratory control and spiked samples. A \%R within the range of 70 to 130 percent indicates satisfactory analytical accuracy (NNSA/NV, 2002).

\subsubsection{Representativeness}

Representativeness is a qualitative evaluation of measurement system performance. It is the degree to which sample data accurately and precisely represent a characteristic of a population, parameter variations at a sampling point, or an environmental condition. Representativeness will be attained by ensuring that the sample locations, analytical parameters, analytical methods, sampling protocols, and sample handling all meet the project-specific objectives.

\subsubsection{Comparability}

Comparability is a qualitative measure that expresses the confidence that one data set can be compared to another. It will be achieved by using standardized field sampling procedures. The same analytical laboratory will perform the same analyses for all samples. Sample results will be reported in standard units to allow for comparison of the data.

\subsubsection{Completeness}

Completeness is a quantitative measure of data quality expressed as the percentage of valid data obtained that satisfies the project-specific requirements. Since a limited number of samples will be collected for both waste characterization and verification of closure, 100 percent of the data collected needs to be of acceptable quality to maintain acceptable QA/QC standards.

\subsubsection{Sensitivity}

Sensitivity is the capability of a method or instrument to discriminate between measurement responses representing different levels of a variable of interest. This indicator is determined from the value of the standard deviation at the concentration level of interest. It represents the minimum difference of concentration that can be distinguished between two samples with a high degree of confidence. Sensitivity must be sufficient to detect contaminants at or below decision levels. Sensitivity will be achieved by analyzing all samples using appropriate EPA-approved analytical laboratories, methods, and instruments. 


\subsection{Permits}

Prior to beginning field closure activities, planning documents and permits will be prepared. These documents will include a National Environmental Policy Act (NEPA) Checklist, a Real Estate/Operations Permit (REOP), Radiological Work Permits (RWPs), excavation permits, and blind penetration permits.

\subsubsection{National Environmental Policy Act Checklist}

A NEPA Checklist will be completed prior to all closure activities at the site. Closure activities will follow all applicable federal, state, and local laws, regulations, and permits regarding protection of the environment.

\subsubsection{Real Estate/Operations Permit}

A REOP will be obtained prior to beginning closure activities. The permit will establish NNSA/NSO as the prime authority possessing control of the site.

\subsubsection{Radiological Work Permit}

RWPs will be required for work at any radiologically impacted site when radiological conditions require, as determined by Health Physics. RWPs will inform workers of the specific PPE necessary to protect them while performing their tasks and identify site-specific controls. The workers will be required to sign the RWPs and acknowledge their understanding of the requirements before entry into any radiologically controlled area, if present. The RWPs will be maintained by the Radiological Control Technician at the entrance to the radiologically controlled area. All site workers will be required to be Radiation Worker II-trained to perform work within a radiologically controlled area.

\subsubsection{Utility Clearances, Excavation Permits, and Blind Penetration Permits}

An excavation permit and a blind penetration permit will be obtained prior to beginning excavation activities. These permits require that a utility clearance be performed. A copy of the permit will be filed onsite throughout the duration of the project. 


\subsection{SCHEDULE}

All preparation and field activities are scheduled for completion in fiscal year 2008. Sufficient flexibility will be incorporated into the field schedule to allow for minor difficulties

(e.g., weather, equipment failure). NNSA/NSO shall notify NDEP of any condition or event that may impact the project schedule. 
CAU 139 CAP

Section: Schedule

Revision: 0

Date: July 2007

THIS PAGE INTENTIONALLY LEFT BLANK 


\subsection{POST-CLOSURE PLAN}

CAS 06-19-03, Waste Disposal Trenches, and CAS 09-23-01, Area 9 Gravel Gertie, will be closed in place with administrative controls, and URs will be implemented to prohibit any unauthorized intrusive activities. Post-closure inspections of these CASs will be required.

\subsection{INSPECTIONS}

Annual site inspections will be completed at CAS 06-19-03, Waste Disposal Trenches, and CAS 09-23-01, Area 9 Gravel Gertie, for 5 years. After the fifth year, inspections will be conducted every 5 years for a total of at least 30 years. Inspections will consist of visual inspections of the postings to verify they are in place and readable and that the UR has been maintained. Any identified maintenance or repair requirements will be reported to NDEP and scheduled within 90 working days of discovery. The inspection report will be incorporated into the combined annual letter report and submitted to the NDEP. The letter report will include a discussion of observations and provide a record of repair or maintenance activities.

\subsection{MONITORING}

As no post-closure sampling or data collection will be performed, no post-closure monitoring is required at any CAS in CAU 139. However, post-closure inspections will be performed as identified above in Section 4.1.

\subsection{MAINTENANCE AND REPAIR}

If any maintenance and repair requirements are identified during site inspections, funding will be requested and the repairs scheduled. Any repair or maintenance performed will be documented in writing at the time of the repair and included in the annual letter report. 
CAU 139 CAP

Section: Post-Closure Plan

Revision: 0

Date: July 2007

THIS PAGE INTENTIONALLY LEFT BLANK 


\subsection{REFERENCES}

DOE, see U.S. Department of Energy.

EPA, see U.S. Environmental Protection Agency.

Federal Facility Agreement and Consent Order. 1996 (as amended). Agreed to by the State of Nevada, the U.S. Department of Energy, and the U.S. Department of Defense.

FFACO, see Federal Facility Agreement and Consent Order.

Murphy, T., Nevada Division of Environmental Protection. 2004. Letter to R. M. Bangerter, Jr. (NNSA/NSO) entitled, "Review of Industrial Sites Project Document 'Guidance for Calculating Industrial Sites Project Remediation Goals for Radionuclides in Soil Using the Residual Radiation (RESRAD) Computer Code,"' 19 November. Las Vegas, NV.

National Council on Radiation Protection and Measurements. 1999. Recommended Screening Limits for Contaminated Surface Soil and Review of Factors Relevant to Site-Specific Studies, NCRP Report No. 129. Washington, DC.

NCRP, see National Council on Radiation Protection and Measurements.

NNSA/NSO, see U.S. Department of Energy, National Nuclear Security Administration Nevada Site Office.

NNSA/NV, see U.S. Department of Energy, National Nuclear Security Administration Nevada Operations Office.

U.S. Department of Energy. 1997. Environmental Measurements Laboratory Procedures Manual, HASL-300, $28^{\text {th }}$ Ed., Vol. 1. New York, NY.

U.S. Department of Energy, National Nuclear Security Administration Nevada Operations Office. 2002. Industrial Sites Quality Assurance Project Plan, Nevada Test Site, Nevada, Revision 3, DOE/NV--372. Las Vegas, NV.

U.S. Department of Energy, National Nuclear Security Administration Nevada Site Office. 2006. Corrective Action Investigation Plan for Corrective Action Unit 139: Waste Disposal Sites, Nevada Test Site, Nevada, DOE/NV--1114. Las Vegas, NV.

U.S. Department of Energy, National Nuclear Security Administration Nevada Site Office. 2007. Corrective Action Decision Document for Corrective Action Unit 139: Waste Disposal Sites, Nevada Test Site, Nevada, DOE/NV--1179. Las Vegas, NV.

U.S. Department of Energy, Nevada Operations Office. 2004. NV/YMP Radiological Control Manual, DOE/NV/11718--079-REV 5. Las Vegas, NV.

U.S. Environmental Protection Agency. 1996. Test Methods for Evaluating Solid Waste Physical/Chemical Methods, SW-846, Third Edition. Washington, D.C. 
CAU 139 CAP

Section: References

Revision: 0

Date: July 2007

THIS PAGE INTENTIONALLY LEFT BLANK 
Revision: 0

Date: July 2007

\section{APPENDIX A.1}

\section{ENGINEERING SPECIFICATION AND DRAWINGS}


CAU 139 CAP

Section: Appendix A.1

Revision: 0

Date: July 2007

THIS PAGE INTENTIONALLY LEFT BLANK

A.1-2 


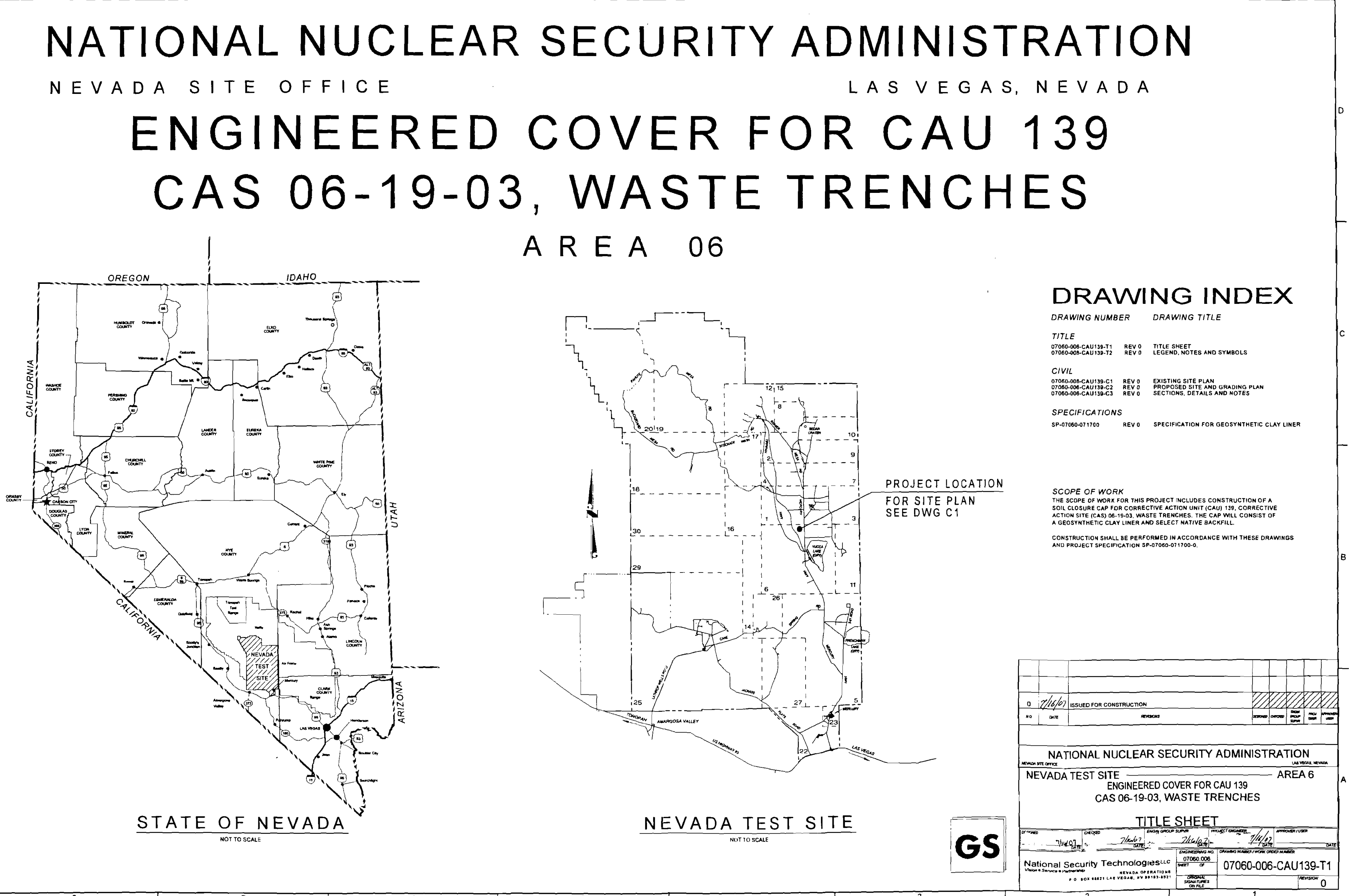




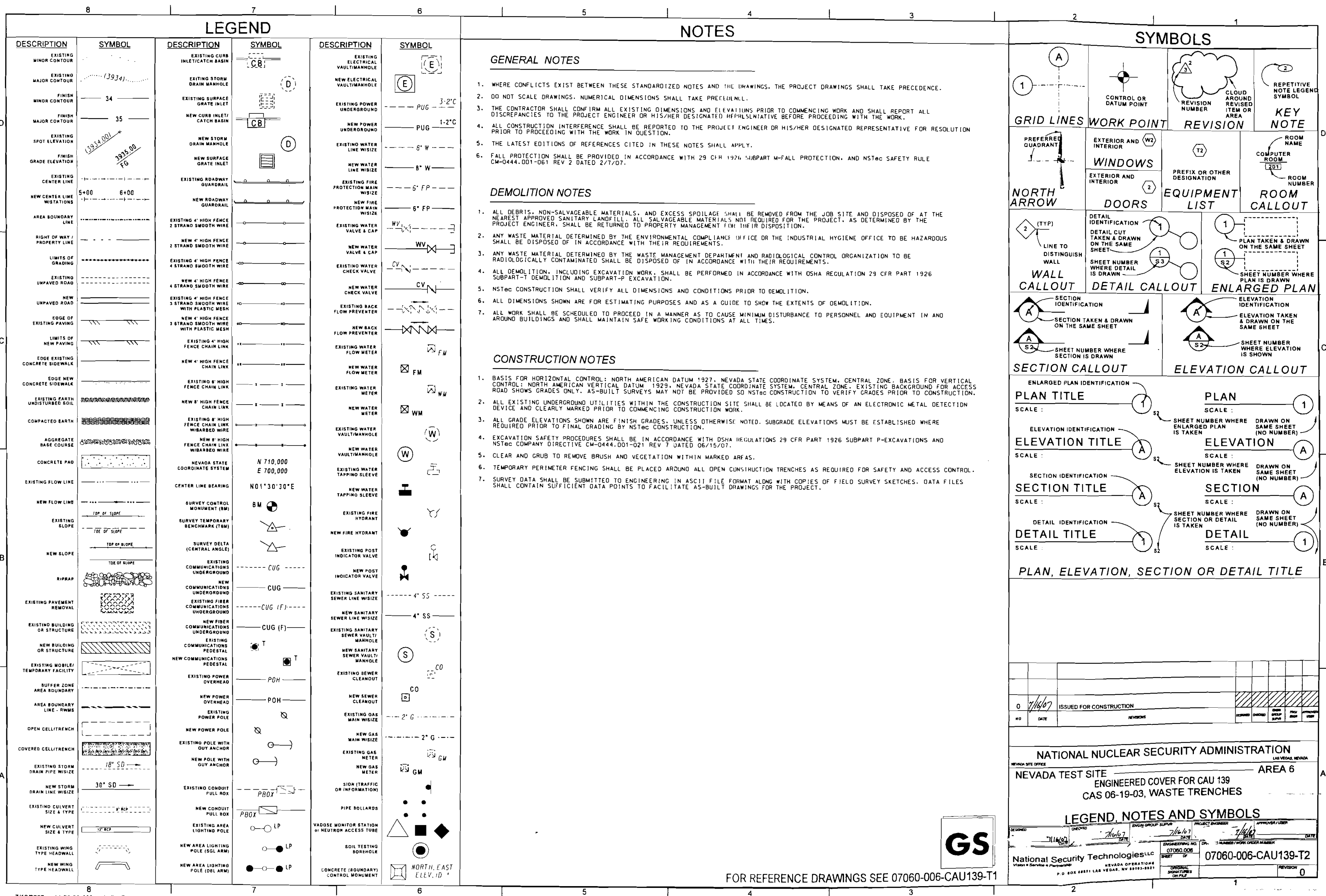




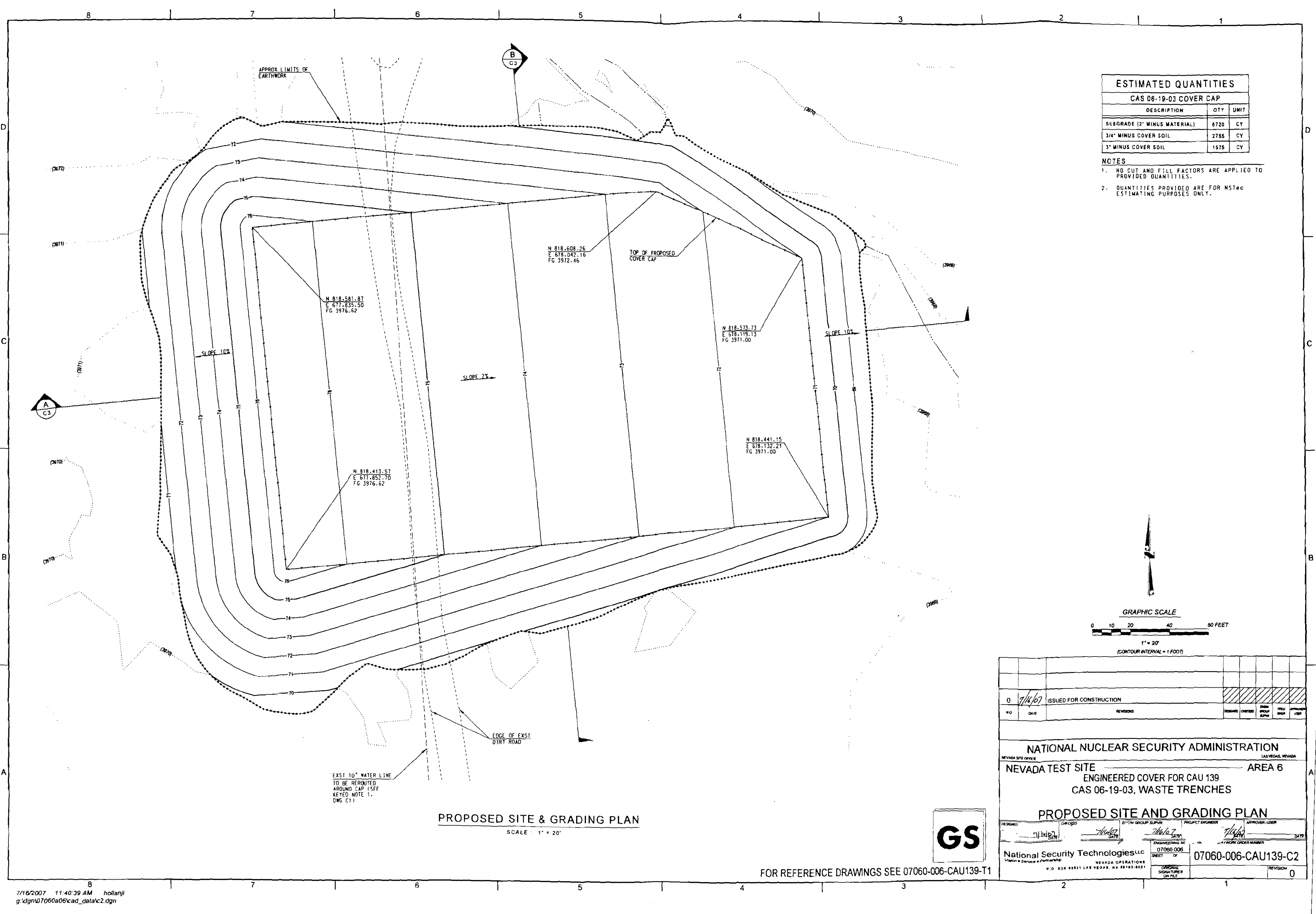




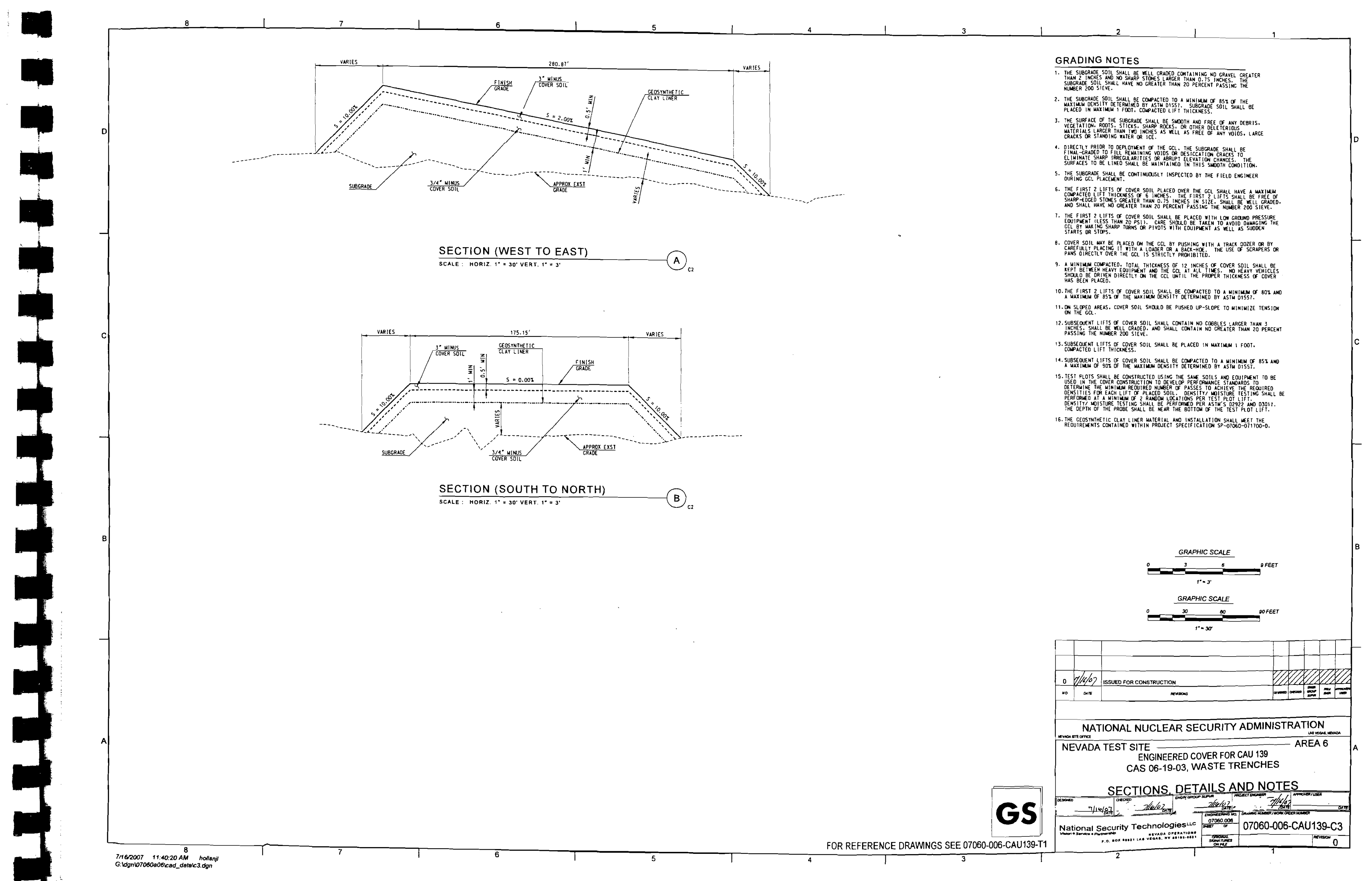




\title{
NTS Construction Specification
}

\author{
SPECIFICATION \\ FOR \\ GEOSYNTHETIC CLAY LINER
}

Engineered Cover for Corrective Action Unit 139

CAS 06-19-03, Waste Trenches

\section{GS}

SPECIFICATION NO. SP-07060-071700-0

\begin{tabular}{|c|c|c|c|c|c|c|}
\hline & & & & & & \\
\hline & & & & & & \\
\hline & & & & & & \\
\hline 0 & & $7 / 16 / 07$ & Issued for Construction & & & \\
\hline REV. & DATE & REASON FOR REVISION & BY & CHK. & EGS & PE \\
\hline
\end{tabular}




\section{Table of Contents}

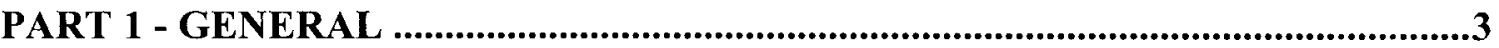

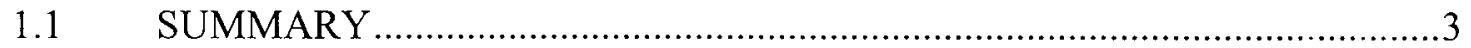

1.2 REFERENCES .............................................................................. 3

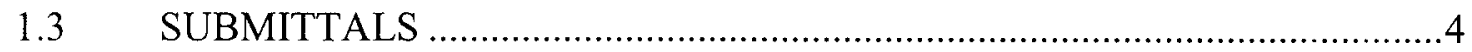

1.4 QUALITY REQUIREMENTS ........................................................... 4

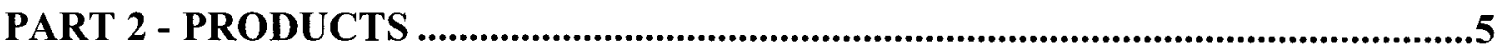

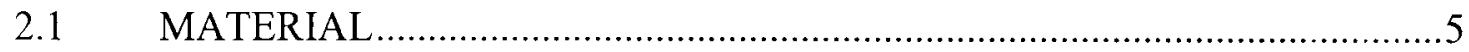

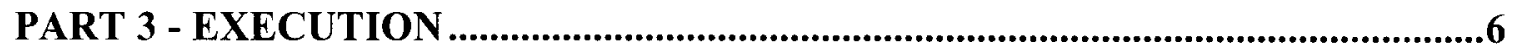

3.1 CONSTRUCTION REQUIREMENTS .............................................6 
PART 1 - GENERAL

\section{$1.1 \quad$ SUMMARY}

A. This specification includes material and installation requirements for a Geosynthetic Clay Liner (GCL) with a polypropylene or HDPE geofilm coating to be placed within a landfill soil closure cap for Corrective Action Unit (CAU) 139, Corrective Action Site (CAS) 06-1903, Waste Trenches. CAS 06-19-03 is located in Area 6 of the Nevada Test Site (NTS). CAS 06-19-03 is located approximately 90 miles north of Las Vegas, Nevada.

\subsection{REFERENCES}

A. American Society of Testing and Materials (ASTM)

1. ASTM D4632-91 (2003), "Standard Test Method for Grab Breaking Load and Elongation of Geotextiles"

2. ASTM D4643-00, "Determination of Water (Moisture) Content of Soil by the Microwave Oven Method"

3. ASTM D5084-03, "Standard Test Method for Measurement of Hydraulic Conductivity of Saturated Porous Materials Using a Flexible Wall Permeameter"

4. ASTM D5261-92 (2003), "Standard Test Method for Measuring Mass Per Unit Area of Geotextiles"

5. ASTM D5321-02, "Determining the Coefficient of Soil and Geosynthetic or Geosynthetic and Geosynthetic Friction by the Direct Shear Method"

6. ASTM D5887-04, "Measurement of Index Flux Through Saturated Geosynthetic Clay Liner Specimens Using a Flexible Wall Permeameter"

7. ASTM D5888-06, "Standard Guide for Storage and Handling of Geosynthetic Clay Liners"

8. ASTM D5889-97 (2003), "Standard Practice for Quality Control of Geosynthetic Clay Liners"

9. ASTM D5890-06, “Standard Test Method for Swell Index of Clay Mineral Component of Geosynthetic Clay Liners"

10. ASTM D5891-02, "Standard Test Method for Fluid Loss of Clay Component of Geosynthetic Clay Liners"

11. ASTM D5993-99 (2004), "Standard Test Method for Measuring Mass Per Unit of Geosynthetic Clay Liners"

12. ASTM D6102-06, "Standard Guide for Installation of Geosynthetic Clay Liners"

13. ASTM D6243-06, "Standard Test Method for Determining the Internal and Interface Shear Resistance of Geosynthetic Clay Liner by the Direct Shear Method" 
14. ASTM D6496-04a, "Standard Test Method for Determining Average Bonding Peel Strength Between the Top and Bottom Layers of Needle-Punched Geosynthetic Clay Liners"

15. ASTM D6768-04, "Standard Test Method for Tensile Strength of Geosynthetic Clay Liners"

16. ASTM E96/E96M-05, "Standard Test Methods for Water Vapor Transmission of Materials"

\subsection{SUBMITTALS}

A. Manufacturer Quality Control Certification - Quality Control certificates shall be submitted by the GCL manufacturer.for each delivery of material. The certifications shall be signed by the quality control manager of the GCL manufacturer or other responsible party and shall include the following information:

1. Shipment Packing List - A list indicating the rolls shipped on a particular truckload.

2. Bill of Lading - The shipping documents for the truck used for the shipment.

3. Letter of Certification - The letter indicating the material is in conformance with the physical properties specified in 2.1.G.

4. Physical Properties Sheet - The material specification for the GCL supplied in accordance with this specification.

B. Manufacturer Quality Control Submittal - Quality Control submittals shall be submitted by the GCL manufacturer for each lot of material. The submittals shall include the following information:

1. Bentonite Manufacturer Certification - Bentonite manufacturer quality documentation for the particular lot of clay used in the production of the rolls delivered.

2. Geotextile Manufacturer Certification - Geotextile manufacturer quality control documentation for the particular lots of geotextiles used in the production of the rolls delivered.

3. GCL Manufacturer Tracking List - Cross referencing list delineating the corresponding geotextile and bentonite lots for the materials used in the production of the rolls delivered.

4. Manufacturing Quality Control Data - The manufacturing quality control test data indicating the actual test values obtained when tested at the appropriate frequencies for the properties specified in 2.1.G.

C. GCL Manufacturer's standard material warranty.

1.4 QUALITY REQUIREMENTS

A. Packaging - All GCL rolls shall be packaged in moisture resistant plastic sleeves. The cardboard cores shall be sufficiently strong to resist collapse during transit and handling. 
B. Roll Identification and Labeling - Prior to shipment, the manufacturer shall label each roll, both on the GCL roll and on the surface of the plastic protective sleeve. Labels shall be resistant to fading and moisture degradation to ensure legibility at the time of the installation. At a minimum the roll labels shall identify the following:

1. Length and width of roll

2. Total weight of roll

3. Type of GCL material

4. Production Lot number and Individual Roll number

\section{PART 2 - PRODUCTS}

\section{$2.1 \quad$ MATERIAL}

A. The GCL product supplied to the project shall be in full accordance with the requirements of this section. The GCL shall be manufactured by mechanically bonding the geotextiles using a needlepunching process to enhance frictional and internal shear strength characteristics.

B. In order to maintain these characteristics, no glues, adhesives or other non-mechanical bonding processes shall be used in lieu of the needlepunch process. Their use to enhance the physical properties of the GCL is permitted.

C. All material shall be new, unused, and undamaged.

D. Dimensions - The minimum acceptable dimensions for the GCL panels shall be 15 feet wide and 125 feet long. Short rolls (rolls less than 125 feet long) may be supplied, but at a rate not to exceed $5 \%$ of the total square footage produced for this project.

E. Overlap Markings - A minimum overlap guide-line and a construction match-line delineating the overlap zone shall be imprinted with non-toxic ink on both edges of the GCL panel to ensure the accuracy of the seam. The minimum overlap guideline shall indicate where the edge of the panel must be placed in order to achieve a full six inches of bentonite overlap for each panel.

F. Accessory Bentonite - Any accessory bentonite used for sealing seams, penetrations, or repairs, shall be the same granular bentonite as used in the production of the GCL itself. 
G. Liner materials shall conform to the following specifications:

\section{Composite GCL or Approved Equivalent}

\author{
Tested Property \\ Geotextile Properties: \\ Cap Nonwoven, oz/yd ${ }^{2}$ \\ Carrier Scrim Woven, oz/yd ${ }^{2}$ \\ Bentonite Properties: \\ Swell Index, $\mathrm{ml} / \mathrm{g}$ \\ Moisture Content, \% \\ Fluid Loss, $\mathrm{ml}$ \\ Finished GCL Properties:

Bentonite, $\mathrm{lb} / \mathrm{ft}^{2}$
Tensile Properties
Tensile Strength, $\mathrm{lb} /$ in
Grab Strength, $\mathrm{lb}$
Grab Elongation, $\%$
Peel Strength, $\mathrm{lb}$
Peel Strength, lb/in
Hydraulic Conductivity, $\mathrm{m} / \mathrm{sec}$
Index Flux, $\mathrm{m}^{3} / \mathrm{m}^{2} / \mathrm{sec}$
Internal Sheer Strength, psf

Test Method

ASTM D5261

ASTM D 5261

ASTM D 5890

ASTM D 4643

ASTM D 5891

ASTM D 5993

ASTM D 6768

ASTM D 4632

ASTM D 4632

ASTM D 4632

ASTM D 6496

ASTM D 5084

ASTM D 5887

ASTM D 6243

\section{Minimum \\ Value}

6.0

3.1

$24 / 2$

$12(\max )$

$18(\max )$

\section{PART 3 - EXECUTION}

\subsection{CONSTRUCTION REQUIREMENTS}

A. The GCL must be supported during handling to ensure worker safety and prevent damage to the liner. The rolls shall not be dragged, lifted from one end, lifted with only the forks of a lift truck or pushed to the ground from the delivery vehicle.

B. Verify that proper handling equipment exists which does not pose any danger to installation personnel or risk of damage or deformation to the liner material itself. Suitable handling equipment is described below:

1. Spreader Bar Assembly - A spreader bar assembly shall include both a core pipe or bar and a spreader bar beam. The core pipe shall be used to uniformly support the roll when inserted through the GCL core while the spreader bar beam will prevent chains or straps from chafing the roll edges. 
2. Stinger - A stinger is a rigid pipe or rod with one end directly connected to a forklift or other handling equipment. If a stinger is used, it should be fully inserted to it's full length into the roll to prevent excessive bending of the roll when lifted.

3. Roller Cradles - Roller cradles consist of two large diameter rollers spaced approximately 3 inches apart, which both support the GCL roll and allow it to freely unroll. The use of roller cradles shall be permitted if the rollers support the entire width of the GCL roll.

4. Straps - Straps may be used to support the ends of spreader bars but are not recommended as the primary support mechanism. As straps may damage the GCL where wrapped around the roll and generally do not provide sufficient uniform support to prevent roll bending or deformation, great care must be exercised when this option is used.

\section{GCL Inspection Upon Delivery -}

1. Each roll shall be visually inspected when unloaded to determine if any packaging or material has been damaged during transit.

2. Rolls exhibiting damage shall be marked and set aside for closer examination during deployment.

3. Minor rips or tears in the plastic packaging shall be repaired with moisture resistant tape prior to being placed in storage to prevent moisture damage.

4. GCL rolls delivered to the project site shall be only those indicated on GCL manufacturing quality control certificates.

D. Storage / Stockpiling / Staging

1. All GCL rolls shall be stock-piled and maintained dry in a flat location area away from high-traffic areas but sufficiently close to the active work area to minimize handling.

2. The presence of free-flowing water within the packaging shall require that roll to be set aside for further examination to ascertain the extent of damage, if any. Freeflowing water within the packaging of unreinforced GCLs shall be cause for rejection of that roll.

3. GCL should be stored no higher than three to four rolls high or limited to the height at which the handling apparatus may be safely handled by installation personnel. Stacks or tiers of rolls should be situated in a manner that prevents sliding or rolling by "choking" the bottom layer of rolls.

4. Rolls shall not be stacked on uneven or discontinuous surfaces in order to prevent bending, deformation, damage to the GCL or cause difficulty inserting the core pipe.

5. An additional tarpaulin or plastic sheet shall be used over the stacked rolls to provide extra protection for GCL material stored outdoors.

6. Bagged bentonite material shall be stored and tarped next to GCL rolls unless other more protective measures are available. Bags shall be stored on pallets or other suitably dry surface which will prevent undue prehydration.

E. Subgrade preparation shall be performed as indicated on the approved drawings. 
F. GCL Orientation - GCL panels should be placed with the nonwoven side up (heat burnished side down) to maximize the shear strength characteristics.

G. GCL Panel Position - Where possible, all slope panels should be installed parallel to the maximum slope while panels installed in flat areas require no particular orientation.

1. Deployment should proceed from the highest elevation to the lowest to facilitate drainage in the event of precipitation.

2. The GCL may be deployed on slopes by pulling the material from a suspended roll

3. Deployment on flat areas shall be conducted in the same manner as that for the slopes, however, care should be taken to minimize "dragging" the GCL. Slip-sheet may be used to facilitate positioning of the liner while ensuring the GCL is not damaged from underlying sources.

4. Overlaps shall be a minimum of 6 inches and be free of wrinkles, folds or "fishmouths".

5. Only install as much GCL that can be covered at the end of the day. No GCL shall be left exposed overnight. The exposed edge of the GCL shall be covered by a temporary tarpaulin or other such water resistant sheeting until the next working day.

H. Seaming - A 6-inch lap line and a 9-inch match line shall be imprinted on both edges of the upper geotextile component of the GCL to assist in installation overlap quality control.

1. Lines shall be printed as continuous dashes in easily observable non-toxic ink.

2. Overlap seams shall be a minimum of six inches on panel edges and one foot on panel ends.

3. Loose granular bentonite should be placed between panel overlaps at a rate of 0.25 pound per lineal foot.

I. Anchor liner panels during installation using sand bags or other means to avoid up-lift and wrinkles.

J. Damage Repair - Prior to and during cover soil placement, damage to the GCL shall be identified and repaired. Damage is defined as any rips or tears in the geotextiles, delamination of geotextiles or a displaced panel.

1. Rip and Tear Repair (Flat Surfaces) - Rips or tears may be repaired by completely exposing the affected area, removing all foreign objects or soil, and by then placing a patch cut from unused GCL over the damage (damaged material may be left in place), with a minimum overlap of 12 inches on all edges. Accessory bentonite should be placed between the patch edges and the repaired material at a rate of a quarter pound per lineal foot of edge spread in a continuous six inch fillet.

2. Rip and Tear Repair (Slopes) - Damaged GCL material on slopes shall be repaired by the same procedures above, however, the edges of the patch should also be adhered to the repaired liner with an adhesive to keep the patch in position during backfill or cover operations. 
3. Displaced Panels - Displaced panels shall be adjusted to the correct position and orientation. The adjusted panel shall then be inspected for any geotextile damage or bentonite loss. Damage shall be repaired by the above procedure.

K. Cover soil shall meet the requirements shown on the approved drawings.

L. $100 \%$ observation by the Field Engineer is required during GCL and cover soil placement.

M. Perform and document all identified and required inspections and tests.

END OF SECTION 071700 


\section{APPENDIX A.2}

\section{SAMPling AND ANALYSis Plan}

NOTE: Sufficient details on the type, number, and location of verification samples to be collected to verify site closure activities have been provided in Sections 2.1.2 and 2.4 of this document. Additionally, sufficient details on waste characterization samples to be collected have been provided in Section 2.1 and 2.4. This Appendix is included here as required by the approved Federal Facility Agreement and Consent Order outline for a Corrective Action Plan. 
CAU 139 CAP

Section: Appendix A.2

Revision: 0

Date: July 2007

THIS PAGE INTENTIONALLY LEFT BLANK

A.2-2 
Revision: 0

Date: July 2007

\section{Appendix A.3}

\section{Project Organization}


CAU 139 CAP

Section: Appendix A.3

Revision: 0

Date: July 2007

THIS PAGE INTENTIONALLY LEFT BLANK

A.3-2 
For this project, the U.S. Department of Energy, National Nuclear Security Administration Nevada Site Office (NNSA/NSO) points of contact are as follows:

NNSA/NSO Federal Industrial Sites Sub-Project Director: Kevin J. Cabble

Telephone Number: (702) 295-5000

NNSA/NSO Task Manager: Sabine Curtis

Telephone Number: (702) 295-0542

The identification of the project Health and Safety Officer and the Quality Assurance Officer can be found in the appropriate plan. However, personnel are subject to change, and it is suggested that the appropriate U.S. Department of Energy Project Manager be contacted for further information. The Task Manager will be identified in the Federal Facility Agreement and Consent Order Monthly Activity Report prior to the start of field activities. 
CAU 139 CAP

Section: Appendix A.3

Revision: 0

Date: July 2007

THIS PAGE INTENTIONALLY LEFT BLANK 
CAU 139 CAP

Section: Library Distribution List

Revision: 0

Date: July 2007

\section{LIBRARY DISTRIBUTION LIST}


CAU 139 CAP

Section: Library Distribution List

Revision: 0

Date: July 2007

THIS PAGE INTENTIONALLY LEFT BLANK 
U.S. Department of Energy

National Nuclear Security Administration

Nevada Site Office

Technical Library

P.O. Box 98518, M/S 505

Las Vegas, NV 89193-8518

U.S. Department of Energy

Office of Scientific and Technical Information

P.O. Box 62

Oak Ridge, TN 37831-0062

Southern Nevada Public Reading Facility

c/o Nuclear Testing Archive

P.O. Box 98521, M/S 400

Las Vegas, NV 89193-8521

Manager, Northern Nevada FFACO

Public Reading Facility

c/o Nevada State Library \& Archives

Carson City, NV 89701-4285
1 (Uncontrolled, electronic copy)

1 (Uncontrolled, electronic copy)

2 (Uncontrolled, electronic copies)

1 (Uncontrolled, electronic copy) 
CAU 139 CAP

Section: Library Distribution List

Revision: 0

Date: July 2007

THIS PAGE INTENTIONALLY LEFT BLANK 